\title{
Temperature and Atomic Oxygen Effects on Helium Leak Rates of a Candidate Main Interface Seal
}

Nicholas Penney

Ohio Aerospace Institute, Brook Park, Ohio

Janice L. Wasowski and Christopher C. Daniels

The University of Akron, Akron, Ohio 


\section{NASA STI Program . . . in Profile}

Since its founding, NASA has been dedicated to the advancement of aeronautics and space science. The NASA Scientific and Technical Information (STI) program plays a key part in helping NASA maintain this important role.

The NASA STI Program operates under the auspices of the Agency Chief Information Officer. It collects, organizes, provides for archiving, and disseminates NASA's STI. The NASA STI program provides access to the NASA Aeronautics and Space Database and its public interface, the NASA Technical Reports Server, thus providing one of the largest collections of aeronautical and space science STI in the world. Results are published in both non-NASA channels and by NASA in the NASA STI Report Series, which includes the following report types:

- TECHNICAL PUBLICATION. Reports of completed research or a major significant phase of research that present the results of NASA programs and include extensive data or theoretical analysis. Includes compilations of significant scientific and technical data and information deemed to be of continuing reference value. NASA counterpart of peer-reviewed formal professional papers but has less stringent limitations on manuscript length and extent of graphic presentations.

- TECHNICAL MEMORANDUM. Scientific and technical findings that are preliminary or of specialized interest, e.g., quick release reports, working papers, and bibliographies that contain minimal annotation. Does not contain extensive analysis.

- CONTRACTOR REPORT. Scientific and technical findings by NASA-sponsored contractors and grantees.
- CONFERENCE PUBLICATION. Collected papers from scientific and technical conferences, symposia, seminars, or other meetings sponsored or cosponsored by NASA.

- SPECIAL PUBLICATION. Scientific, technical, or historical information from NASA programs, projects, and missions, often concerned with subjects having substantial public interest.

- TECHNICAL TRANSLATION. Englishlanguage translations of foreign scientific and technical material pertinent to NASA's mission.

Specialized services also include creating custom thesauri, building customized databases, organizing and publishing research results.

For more information about the NASA STI program, see the following:

- Access the NASA STI program home page at http://www.sti.nasa.gov

- E-mail your question via the Internet to help@ sti.nasa.gov

- Fax your question to the NASA STI Help Desk at 443-757-5803

- Telephone the NASA STI Help Desk at 443-757-5802

- Write to: NASA Center for AeroSpace Information (CASI) 7115 Standard Drive Hanover, MD 21076-1320 


\section{Temperature and Atomic Oxygen Effects on Helium Leak Rates of a Candidate Main Interface Seal}

Nicholas Penney

Ohio Aerospace Institute, Brook Park, Ohio

Janice L. Wasowski and Christopher C. Daniels

The University of Akron, Akron, Ohio

Prepared for the

46th Joint Propulsion Conference and Exhibit

cosponsored by the AIAA, ASME, SAE, and ASEE

Nashville, Tennessee, July 25-28, 2010

Prepared under Contract NNC08CA35C

National Aeronautics and

Space Administration

Glenn Research Center

Cleveland, Ohio 44135 


\section{Acknowledgments}

The authors wish to acknowledge the following organizations that contributed to this research: Analex Corporation for design and engineering support; OCM Test Laboratories for the elastomer outgas testing; Parker Hannifin Corporation's Composite Sealing Systems Division for supplying the test articles; National Aeronautics and Space Administration (NASA) Glenn Research Center's (GRC) Space Environment and Experiments Branch for exposing test specimens to atomic oxygen; and NASA GRC's Tribology and Mechanical Components Branch for supplying the test apparatus and funding. Additionally, the authors wish to acknowledge Erhard Hartman for his technical support during this study. This work was supported by the NASA under contract NNC08CA35C.

Trade names and trademarks are used in this report for identification only. Their usage does not constitute an official endorsement, either expressed or implied, by the National Aeronautics and Space Administration.

Level of Review: This material has been technically reviewed by NASA expert reviewer(s).

Available from

NASA Center for Aerospace Information 7115 Standard Drive

Hanover, MD 21076-1320
National Technical Information Service 5301 Shawnee Road Alexandria, VA 22312

Available electronically at http://gltrs.grc.nasa.gov 


\title{
Temperature and Atomic Oxygen Effects on Helium Leak Rates of a Candidate Main Interface Seal
}

\author{
Nicholas Penney \\ Ohio Aerospace Institute \\ Brook Park, Ohio 44142 \\ Janice L. Wasowski and Christopher C. Daniels \\ The University of Akron \\ Akron, Ohio 44325
}

\begin{abstract}
Helium leak tests were completed to characterize the leak rate of a 54 in. diameter composite space docking seal design in support of the National Aeronautics and Space Administration's (NASA's) Low Impact Docking System (LIDS). The evaluated seal design was a candidate for the main interface seal on the LIDS, which would be compressed between two vehicles, while docked, to prevent the escape of breathable air from the vehicles and into the vacuum of space. Leak tests completed at nominal temperatures of $-30,20$, and $50{ }^{\circ} \mathrm{C}$ on untreated and atomic oxygen (AO) exposed test samples were examined to determine the influence of both test temperature and AO exposure on the performance of the composite seal assembly. Results obtained for untreated seal samples showed leak rates which increased with increased test temperature. This general trend was not observed in tests of the AO exposed specimens. Initial examination of collected test data suggested that AO exposure resulted in higher helium leak rates, however, further analysis showed that the differences observed in the 20 and $50{ }^{\circ} \mathrm{C}$ tests between the untreated and AO exposed samples were within the experimental error of the test method. Lack of discernable trends in the test data prevented concrete conclusions about the effects of test temperature and AO exposure on helium leak rates of the candidate seal design from being drawn. To facilitate a comparison of the current test data with results from previous leak tests using air as the test fluid, helium leak rates were converted to air leak rates using standard conversion factors for viscous and molecular flow. Flow rates calculated using the viscous flow conversion factor were significantly higher than the experimental air leakage values, whereas values calculated using the molecular flow conversion factor were significantly lower than the experimentally obtained air leak rates. The difference in these sets of converted flow rates and their deviation from the experimentally obtained air leak rate data suggest that neither conversion factor can be used alone to accurately convert helium leak rates to equivalent air leak rates for the test seals evaluated in this study; other leak phenomena, including permeation, must also be considered.
\end{abstract}

\section{Nomenclature}

$t_{0} \quad$ time constant

\section{Introduction}

To successfully accomplish the Constellation Mission, the National Aeronautics and Space Administration (NASA) required a new docking system with advanced capabilities. The Low Impact Docking System (LIDS) was designed to dock with a variety of manned and autonomous vehicles with minimal forces imparted upon either vehicle. The system was intended to be lighter weight, and to reduce the risks associated with docking.

The docking system required a seal at the interface between the two vehicles to maintain the gas pressure inside the adjoining vehicles and minimize the leakage of breathable air from the cabin to the vacuum of space. This seal, referred to as the main interface seal, was $54 \mathrm{in}$. in diameter and was designed to withstand the harsh environments of Low Earth Orbit (LEO) and outer space. The operating environment of the docking system was expected to subject the main interface seal to temperatures between -75 and $125{ }^{\circ} \mathrm{C}$. The seal was designed to function mechanically (i.e., be compressed) at temperatures between -50 and $75^{\circ} \mathrm{C}$. The requirements of the docking system stipulated that the seal maintain low leak rates at temperatures of 4 to $40^{\circ} \mathrm{C}$.

Considering the docking system's exposure temperature range, silicone elastomers were chosen as seal system candidates based upon prior successful use in space applications, a capability to survive exposure to harsh 
temperatures, and an ability to be formed into seals. Select silicone elastomers could also meet other program requirements, including being low outgassing (Ref. 1).

One candidate seal design consisted of a composite of a metal retainer and four elastomer seal bulbs that were vacuum molded into the retainer. The metal retainer provided a means to fasten the one piece assembly to the docking system, and limited the compression of the elastomer during docking. Additionally, the retainer minimized the ability of the elastomer to be removed undesirably during undocking (Ref. 2).

Although silicone elastomers offer a wide operating temperature range, they are more permeable to gases than many other elastomer compounds. Additionally, the permeation rate of silicone elastomers varies with temperature and gas type (Ref. 3). This combination of characteristics necessitates that the leak rate behavior of silicone elastomers be thoroughly investigated prior to application on flight vehicles.

Elastomers tend to adhere to contact surfaces (Ref. 4). Adhesion levels depend upon many factors, including the elastomer compound, temperature, amount and duration of contact, amongst others. Adhesion mitigation techniques include lubrication and controlling the temperature of the interface during separation. Another effective technique for minimizing adhesion is the pretreatment of the seal's elastomer surfaces with atomic oxygen (AO). Studies have shown that moderate exposure to $\mathrm{AO}$ can reduce or eliminate surface adhesion (Ref. 5). A minor drawback to the AO pretreatment technique is a modest increase in the leak rate of the seal (Ref. 6).

Previous investigations to characterize leak rates have been conducted on seals of similar designs using dry air as the test gas (Ref. 7). While useful in understanding the behavior in application, dry air is rarely utilized during qualification, acceptance, and verification testing processes. Tracer gases (usually helium) are used because of their small size and tendency to readily permeate through porous media. Using proper techniques and procedures, tracer gas methods can accurately predict very small leak rates.

In this work, a helium leak detector was used to quantify the leak rate of four 54 in. diameter candidate composite seal assembly test specimens. A full factorial matrix of tests was conducted using test temperatures of $-30,20$, and $50{ }^{\circ} \mathrm{C}$ on test specimens with and without $\mathrm{AO}$ surface pretreatment. The effects of test temperature and surface pretreatment on the seal leak rates, as well as a comparison of air leak rates to helium leak rates are discussed.

\section{A. Test Specimens}

\section{Description of Experiments}

Each test specimen consisted of four individual elastomer seals vacuum molded into a metal retainer, as shown in Figure 1. There were two back seals and two front seals. The two front seals had identical cross-sections, and the two back seals had identical cross-sections, though the front and back seals were different. The dimensions of the seals are proprietary and therefore are not reported. The front and back seals closest to the inner diameter are referred to as the primary seals, and the front and back seals closest to the outer diameter are referred to as the redundant seals. The seal assemblies were manufactured per a design referred to as EDU54 using Parker-Hannifin S0383-70 silicone elastomer compound. The metal retainer was manufactured from aluminum 7075-T651 with a chemical conversion coating applied per Mil-C-5541 (Ref. 8) to minimize corrosion. The test specimen's silicone elastomer met mission outgas requirements of total mass loss (TML) less than $1.0 \%$ and collected volatile condensable materials (CVCM) less than 0.1\% when tested per ASTM E595 (Ref. 9).

The specimens were tested in one of two conditions. Two specimens were tested as received from the manufacturer, without surface pretreatment. These specimens' sealing surfaces were cleaned prior to testing with lint free wipes moistened with isopropyl alcohol to remove any accumulated debris, and then allowed to dry for a minimum of $15 \mathrm{~min}$. Two additional test specimens were pretreated with an $\mathrm{AO}$ fluence of approximately $10^{20}$ atoms $/ \mathrm{cm}^{2}$. These AO exposures were conducted at NASA GRC according to the ASTM E 2089 specification (Ref. 10). Prior to pretreatment, these specimens were cleaned as described above. After pretreatment, cleaning was limited to lightly blowing the sealing surfaces with canned compressed air to remove any accumulated debris.

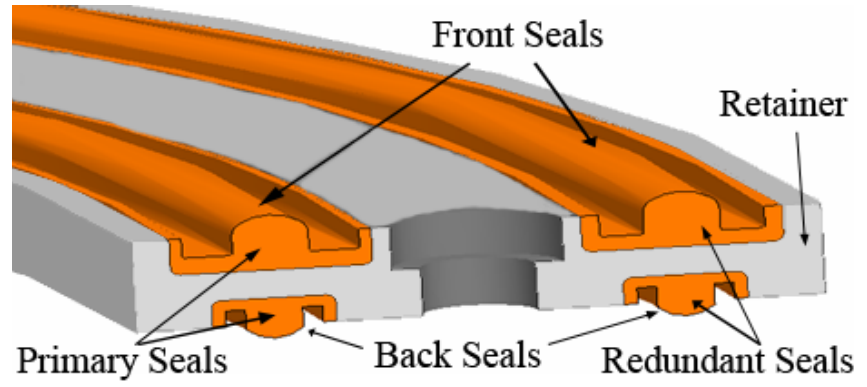

Figure 1.-Representative illustration of a composite seal assembly. 


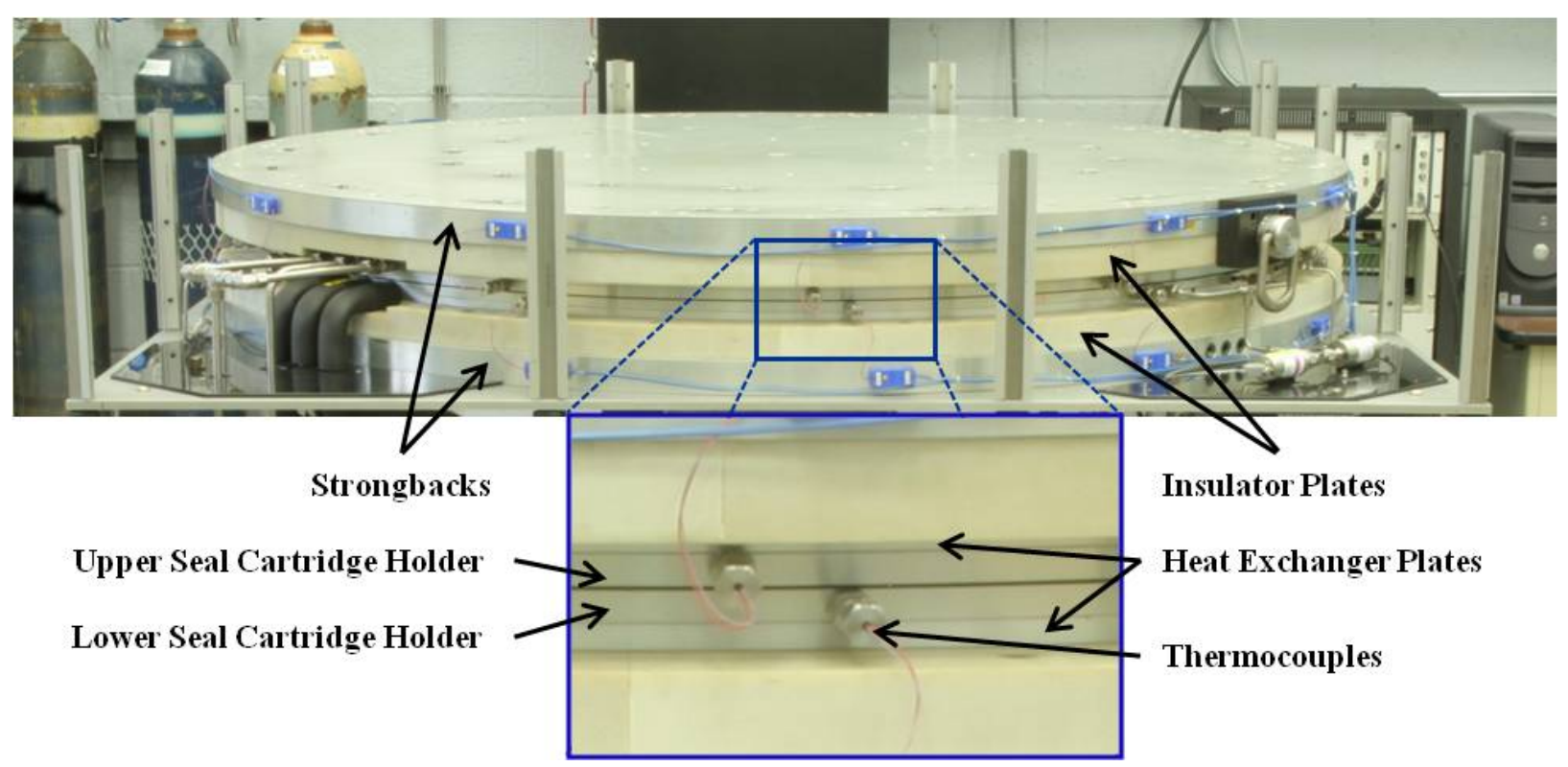

Figure 2.-Photograph of non-actuated full-scale flow fixture.

\section{B. Leak Test System}

Helium leak rates of the candidate main interface seal specimens were determined using the non-actuated fullscale flow fixture, as shown in Figure 2 (Ref. 11). The flow fixture was comprised of two primary assemblies, an upper assembly and a lower assembly, which were nearly identical. The foundation of each assembly was a $2 \mathrm{in}$. thick aluminum "strongback" plate to which the other components of the assembly were attached with mechanical fasteners. These components, moving from the strong back to the test interface, included a phenolic thermal insulator plate, a heat exchanger plate, and a seal cartridge holder. Those components were identical on both the upper and lower assemblies.

The test seal assembly was attached to the lower seal cartridge holder with 72 fasteners. These fasteners applied the preload required to fully compress the test sample's back seals against the anodized surface ( $32 \mu \mathrm{in}$. surface finish) of the seal cartridge holder, resulting in metal-to-metal contact between the test seal retainer and the seal cartridge holder. During testing, the test specimen's front seals mated against an anodized aluminum mating counter-face plate (7075-T6 Al, $16 \mu$ in. surface finish) that was fastened to the upper seal cartridge holder. To minimize leakage between the mating counter-face plate and the upper seal cartridge holder, two silicone O-rings were installed in grooves in the back side of the mating counter-face plate. The upper assembly was then positioned over the lower assembly such that the test seal aligned and mated with the mating counter-face plate. Twenty-four external fasteners were installed through the two halves of the flow fixture. The fasteners were then tightened to simulate latching loads that would be generated across the sealing interface by the LIDS on orbit. The assembled flow fixture isolated the test section from the ambient environment with the inner and outer isolation o-rings, as shown in Figure 3. The test section encompassed the test specimen, mating counter-face plate, and the outer annulus.

Once the flow fixture was assembled, the outer annulus was evacuated through a vacuum port. This was accomplished with a Varian Model 979 series Helium Mass Spectrometer leak detector, with a manufacturer stated accuracy of 2\%, and a Varian Triscroll 600 rough vacuum pump. During testing, the rough pump was isolated from the test section, so that none of the test gas was diverted from the leak detector.

A helium leak standard was used to calibrate the helium leak detector at the beginning or end of each leak test, depending on the test. The leak standard was either a VIC Leak Detection glass orifice, with an uncertainty of $\pm 10 \%$, or a LACO Technologies Micro-tube capillary orifice, with an accuracy of $\pm 3.8 \%$. Both had a leak rate in the range of the test specimens and were mounted to the non-actuated full-scale flow fixture at a port opposite the vacuum port. Helium from the leak standard circulated around the outer annulus and not through the test specimen. During the calibration process, the time constant, $t_{0}$, which was the time required for the helium leak detector to indicate a steady-state leak was determined. 


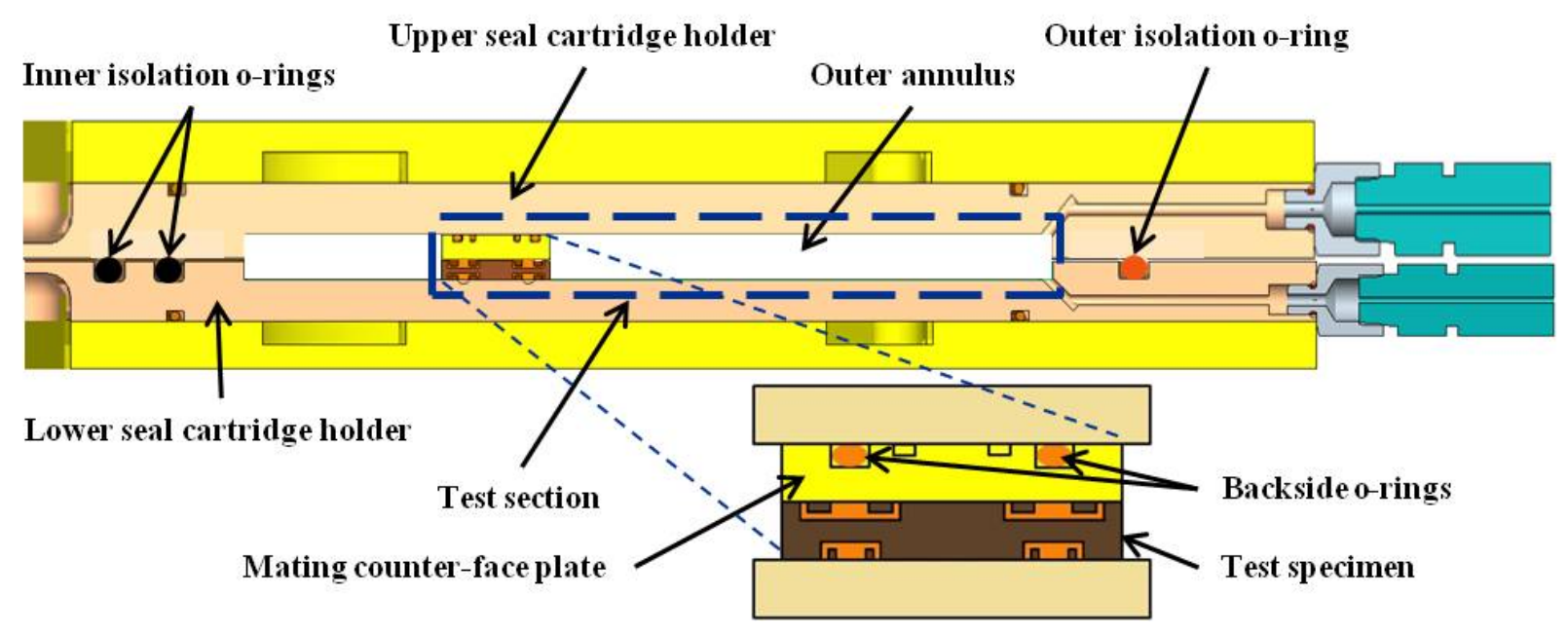

Figure 3.-Illustration of assembled test section with magnification of test specimen and mating counter-face.

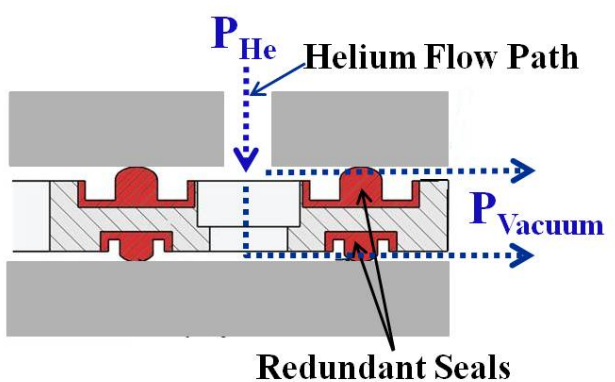

Figure 4.-Illustration of helium flow path.

During testing, high purity helium (99.997\%) was supplied between the inner and outer test specimen seals at 0.2 psig, as shown in Figure 4. With a constant helium supply, helium permeated through both the primary and redundant seals, but only the helium that passed through the redundant seals to the outer annulus was measured. The duration of time that helium was supplied to the test specimen included the time required for the test specimen leak rate to reach steady-state and three time constants.

\section{Thermal Control System}

The temperature of the test specimens was controlled using a Mydax 2VLH30W Chiller/Heater unit, which circulated Dow Syltherm HF heat transfer fluid through passages in heat exchanger plates attached to the backside of the upper and lower seal cartridge holders (Fig. 2). The temperature control unit maintained the test section temperature to $\pm 0.5{ }^{\circ} \mathrm{C}$. The test section temperature was monitored with 24 evenly spaced circumferentially mounted type-T thermocouples (Fig. 2), distributed equally on the upper and lower seal cartridge holders. Each thermocouple had an accuracy of $\pm 0.036^{\circ} \mathrm{C}$.

\section{Data Acquisition System}

A PC based data acquisition system was used to display and record the test data. National Instruments hardware and a custom written LabVIEW (National Instruments) code collected the interbulb pressure, the outer annulus vacuum pressure, the test section temperatures, and the helium leak rate. Unfiltered data was sampled at $25 \mathrm{~Hz}$ and recorded every $10 \mathrm{sec}$ with each recorded value being an average of 25 sampled data points. 


\section{Experimental Results and Discussion}

As shown in Figure 5, the leak detector data from a typical leak test contained five distinct regions. Regions I and II represented the data from the leak standard. Region I represented the time it took the leak detector to indicate a steady-state leak rate, $t_{0}$. During the analysis of the test data, $t_{0}$ was used in the determination of the test specimen's leak rates. Region II represented the steady-state leak rate of the leak standard. Region III represented the system clean-up where the helium introduced by the leak standard into the test section, and subsequently the leak detector, was removed from the system. The next regions of the graph characterized the performance of the test specimen. Region IV represented the rise to steady-state, and Region V showed the steady-state leak rate of the test specimen.

For each test, the helium leak rate for the test specimen was calculated from the averaged steady-state measurements in Region V. The results are summarized in Table 1. The reported leak rates represented the arithmetic average of two tests conducted at each temperature for both the untreated and AO exposed test specimens. These leak rates were normalized per unit length based on the circumferential length of the redundant seal bulb centerline. This allowed comparison between the tests conducted with helium, which measured the leak rate of the redundant seal bulbs, and previously reported tests conducted with air (Ref. 7), which measured the leak rate of the primary seal bulbs. The experimental error for the results shown in Table 1 was $\pm 33 \%$ of the reading.

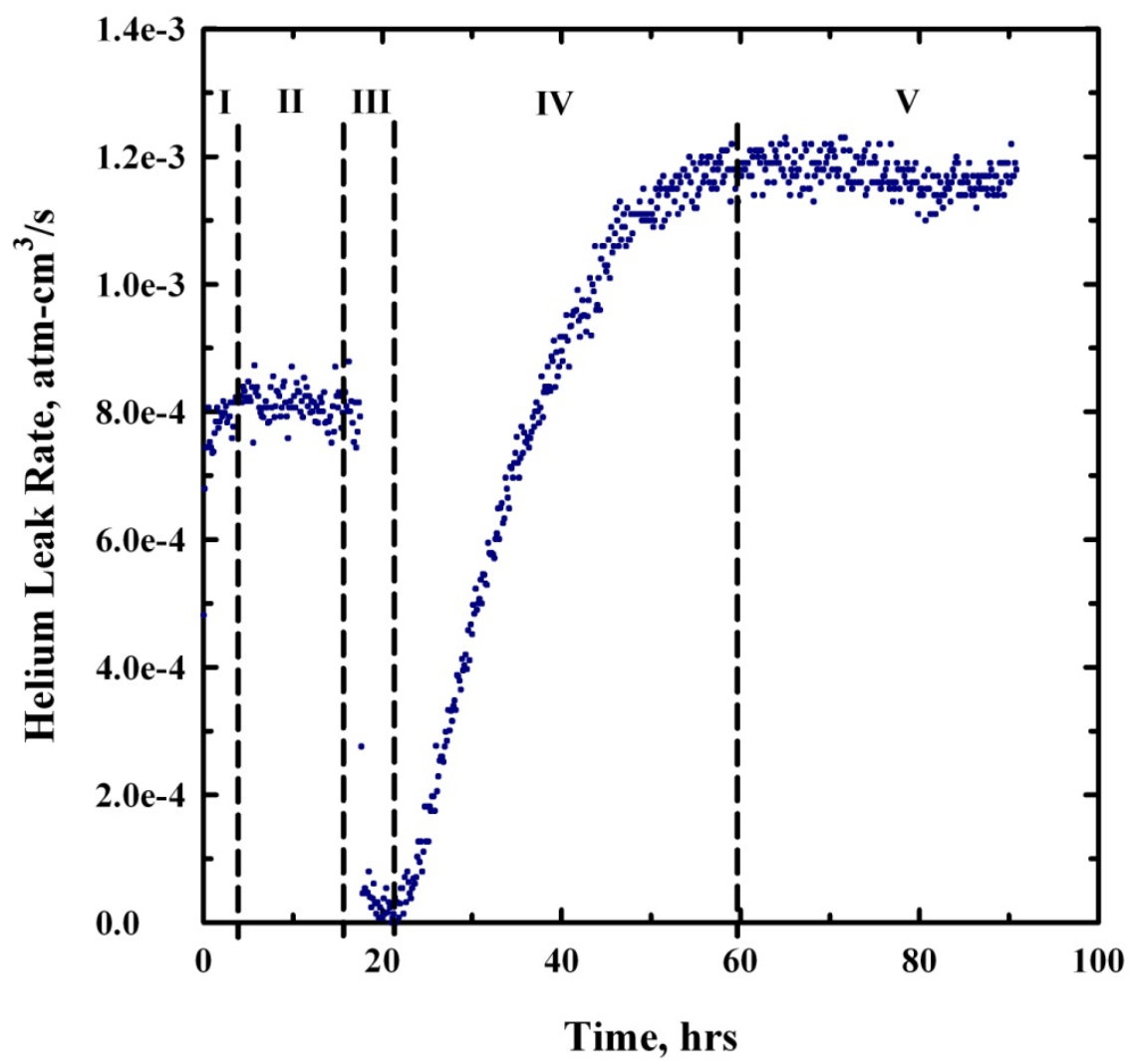

Figure 5.-Typical leak rate test data.

TABLE 1.-HELIUM LEAK RATE RESULTS

\begin{tabular}{|c|c|c|}
\hline Temperature, ${ }^{\circ} \mathrm{C}$ & \multicolumn{2}{|c|}{$\begin{array}{c}\text { Helium Leak Rate, } \\
\text { atm-cc/s-in. }\end{array}$} \\
\cline { 2 - 3 } & Untreated & AO exposed \\
\hline-30 & $2.09 \times 10^{-6}$ & $1.24 \times 10^{-5}$ \\
\hline 20 & $5.91 \times 10^{-6}$ & $6.63 \times 10^{-6}$ \\
\hline 50 & $1.33 \times 10^{-5}$ & $1.51 \times 10^{-5}$ \\
\hline
\end{tabular}




\section{A. Temperature Effects on Leak Rate}

The helium leak rates for the test specimens were measured at three test temperatures: $-30,20$, and $50{ }^{\circ} \mathrm{C}$. The leak rates for the untreated test specimens increased as the temperature increased, as shown in Figure 6. This result followed the trend of previously reported air leak rates for the same test specimens at the same test conditions (Ref. 7). The temperature effect on the test specimens exposed to $\mathrm{AO}$ was not as straight forward. As shown in Figure 6 the leak rate increased as the temperature increased from 20 to $50{ }^{\circ} \mathrm{C}$, however, the leak rate also appeared to have increased as the temperature decreased from 20 to $-30{ }^{\circ} \mathrm{C}$. This did not correspond to the trend observed for the air leak rate results; the air leak rate results showed an increase in leak rate with temperature similar to the leak rates of the untreated test specimens. A contributing factor to the differences could be the associated test equipment. It has been shown that measurement error can occur when the nontemperature compensated leak detector was used for test conditions other than room temperature (Ref. 12). Although this was not apparent in the untreated seal test results, it is a factor that requires further investigation.

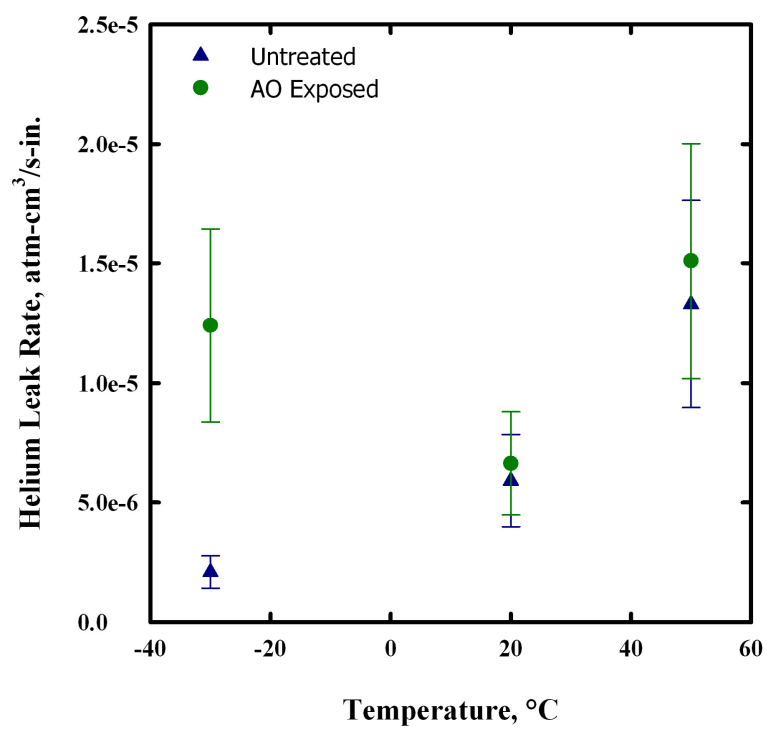

Figure 6.-Comparison of untreated and AO exposed test specimens.

\section{B. AO Exposure Effects on the Leak Rate}

When the leak rates of the untreated test specimens were compared to the leak rates of AO exposed test specimens, the leak rates for the AO exposed specimens appeared greater than the leak rates of the untreated specimens, as shown in Figure 6. However, this observed increase for the 20 and $50{ }^{\circ} \mathrm{C}$ tests was within the experimental error of the tests and the increase was not considered significant. At $-30{ }^{\circ} \mathrm{C}$, the average leak rate of the $\mathrm{AO}$ exposed test specimens was approximately 5.9 times greater than that of the untreated specimens.

\section{Comparison of Helium Leak Rates to Air Leak Rates}

To compare the helium leak rates reported here with the previously reported air leak rates (Ref. 7), differences in the type of measurement (volume versus mass) and the type of gas (helium versus air) needed to be addressed. The conversion from a volumetric leak rate to a mass leak rate was accomplished using the density of the gas. However, the conversion from helium to air was not straight forward. Conversion factors typically used in industry for converting helium leak rates to air are 1.08 and 0.374 for viscous flow and molecular flow respectively. The viscous flow conversion factor is the ratio of the dynamic viscosity of the two gases, and the molecular flow conversion factor is the ratio of the average molecular velocity of the two gases (Ref. 13). In both the viscous and molecular flow cases, the conversion factors are based on flow through an orifice of finite dimensions, however, based on previous work, it was shown that the flow through these test specimens was dominated by permeation (Ref. 6). Permeation does not rely on physical defects in the material to provide a leak path as required for viscous and molecular flow leaks. Therefore, applying viscous or molecular flow conversion factors to permeation dominated leak rates can produce erroneous results.

As an example, the helium leak rates reported for the untreated test specimens were converted to equivalent air leak rates using both the viscous flow and molecular flow conversion factors. The resulting converted air leak rates were then compared to the previously reported experimental air leak rates for the same test specimens at the same temperature and test conditions. Using a NIST traceable leak standard, the pressure decay mass loss technique has been shown to have less uncertainty associated with the results when compared to the helium leak detector method (Ref. 12). Therefore, the experimentally determined air leak rates were considered the most accurate. A comparison of the converted air leak rates and the experimental air leak rates is summarized in Table 2. As shown in Table 2, when viscous flow was assumed, the converted air leak rates were 35 to $73 \%$ greater than the experimental air leak rates, however, when molecular flow was assumed, the converted air leak rates were 40 to $53 \%$ less than the 
TABLE 2.-COMPARISON OF HELIUM AND AIR LEAK RATES

\begin{tabular}{|c|c|c|c|c|c|c|}
\hline $\begin{array}{c}\text { Temperature, } \\
{ }^{\circ} \mathrm{C}\end{array}$ & $\begin{array}{c}\text { Helium leak } \\
\text { rate }\end{array}$ & \multicolumn{2}{|c|}{ Converted air leak rate } & $\begin{array}{c}\text { Experimental air } \\
\text { leak rate (Ref. 7) }\end{array}$ & \multicolumn{2}{|c|}{$\begin{array}{c}\text { Experimental to } \\
\text { converted leak rate ratio }\end{array}$} \\
\cline { 2 - 7 } & atm-cc/s-in. & $\begin{array}{c}\text { Viscous flow } \\
\text { lbm/s-in. }\end{array}$ & $\begin{array}{c}\text { Molecular flow } \\
\text { lbm/s-in. }\end{array}$ & lbm/s-in. & $\begin{array}{c}\text { Viscous } \\
\text { flow }\end{array}$ & $\begin{array}{c}\text { Molecular } \\
\text { flow }\end{array}$ \\
\hline-30 & $2.09 \times 10^{-6}$ & $7.24 \times 10^{-12}$ & $2.51 \times 10^{-12}$ & $5.15 \times 10^{-12}$ & 0.71 & 2.05 \\
\hline 20 & $5.91 \times 10^{-6}$ & $1.70 \times 10^{-11}$ & $5.88 \times 10^{-12}$ & $1.26 \times 10^{-11}$ & 0.74 & 2.14 \\
\hline 50 & $1.33 \times 10^{-5}$ & $3.47 \times 10^{-11}$ & $1.20 \times 10^{-11}$ & $2.00 \times 10^{-11}$ & 0.57 & 1.67 \\
\hline
\end{tabular}

experimental air leak rates. In both cases, when the helium leak rates were converted to air leak rates, the results were significantly different than the experimental air leak rate values. This example highlights the importance of understanding the type of flow and test conditions when leak testing with helium and then converting the results to leak rates for other gases.

\section{Summary}

A near-full-scale candidate composite seal assembly to be used as the main interface seal of the LIDS has been helium leak tested. From the experimental results, the following observations were noted:

1. The helium leak rate for the untreated test specimens increased as the temperature increased over the temperature range of -30 to $50{ }^{\circ} \mathrm{C}$, however, the helium leak rate for the $\mathrm{AO}$ exposed test specimens decreased over the temperature range of -30 to $20^{\circ} \mathrm{C}$ then increased as the temperature increased over the temperature range of 20 to $50^{\circ} \mathrm{C}$. The inconsistent trend requires further investigation.

2. There was an apparent increase in the helium leak rate of test specimens exposed to AO when compared to untreated test specimens over the temperature range of 20 to $50{ }^{\circ} \mathrm{C}$. However, the differences were within the experimental error of the tests and the increase was not deemed significant. There was a significant increase in the helium leak rate of test specimens exposed to $\mathrm{AO}$ when compared to untreated test specimens at $-30^{\circ} \mathrm{C}$.

3. Using standard conversion factors for viscous or molecular flow can produce inaccurate results when applied to this study's test specimens. The test specimen seal leakage was dominated by permeation, which exhibits different flow behavior than either viscous or molecular flow.

\section{References}

1. Daniels, C.C., de Groh III, H., Dunlap, P.H., Finkbeiner, J.R., Steinetz, B.M., Bastrzyk, M.B., Oswald, J.J., Banks, B.A., Dever, J.A., Miller, S.K., and Waters, D.L., "Characteristics of Elastomer Seals Exposed to Space Environments," Proceedings of the 43rd AIAA/ASME/SAE/ASEE Joint Propulsion Conference \& Exhibit, No. AIAA-2007-5741, AIAA, Cincinnati, OH, 8-11 July 2007.

2. Conrad, M.C., Daniels, C.C. and Bastrzyk, M.B., "An Experimental Investigation of Silicone-to-Metal Bond Strength in Composite Space Docking System Seals," Proceedings of the 45th AIAA/ASME/SAE/ASEE Joint Propulsion Conference \& Exhibit, No. AIAA-2009-5320, AIAA, Denver, Colorado, 2-5 August 2009.

3. Pauly, S., "Permeability and Diffusion Data," Polymer Handbook, 4th ed., edited by J. Brandrup, E.A. Immergut, and E.A. Grulke, Wiley-Interscience, New York, 1999, Chap. VI.

4. Bastrzyk, M.B. and Daniels, C.C., "The Mechanical Performance of Subscale Candidate Elastomer Docking Seals," $51^{\text {st }}$ AIAA/ASME/ASCE/AHS/ASC Structures, Structural Dynamics, and Materials Conference, April 2010.

5. Garafolo, N.G., Bastrzyk, M.B., and Daniels, C.C., "The Effects of Atomic Oxygen on the Sealing and Mechanical Performance of an Elastomer Seal," Proceedings of the 48th AIAA Aerospace Sciences Meeting, No. AIAA-2010-1440, AIAA, Orlando, Florida, 4-7 January 2010.

6. Smith, I.M., Daniels, C.C., Dunlap, P.H., and Steinetz, B.M., "Performance of Sub-scale Docking Seals under Simulated Temperature Conditions," Proceedings of the 44rd AIAA/ASME/SAE/ASEE Joint Propulsion Conference \& Exhibit, No. AIAA-2008-4713, AIAA, Hartford, CT, 21-23 July 2008.

7. Wasowski, J.L., Penney, N., Garafolo, N.G., and Daniels, C.C., "Leak Rates of a Candidate Main Interface Seal at Selected Temperatures," Proceedings of the 45th AIAA/ASME/SAE/ASEE Joint Propulsion Conference \& Exhibit, No. AIAA-2009-5320, AIAA, Denver, Colorado, 2-5 August 2009.

8. USN. MIL-C-5541E: Chemical Conversion Coatings on Aluminum and Aluminum Alloys. Department of Defense, 1990. 
9. ASTM International. ASTM E595-07 (Reapproved 2003): Standard test method for total mass loss and collected volatile on densable materials from outgassing in a vacuum environment. 2003.

10. ASTM International. ASTM E-2089-00 (Reapproved 2006): Standard Practices for Ground Laboratory Atomic Oxygen Interaction Evaluation of Materials for Space Applications. ASTM, 2006.

11. Dunlap, P.H., Daniels, C.C., Steinetz, B.M., Erker, A.H., Robbie, M.G., Wasowski, J.L., Drlik, G.J., Tong, M.T., and Penney, N., "Full-Scale System for Quantifying Leakage of Docking System Seals for Space Applications," NASA/TM-2007-215024, AIAA-2007-5742, October 2007.

12. Daniels, C.C. and Garafolo, N.G., "Comprehensive Mass Point Leak Rate Technique. Part II: Application of Methodology and Variable Influences," The Fourth Japan-US Symposium on Emerging NDE Capabilities for a Safer World, American Society for Nondestructive Testing, Maui, HI, June 7-11, 2010.

13. VanAtta, C.M., Vacuum Science and Engineering, McGraw-Hill, New York, 1965, pp. 44-62. 


\begin{tabular}{|c|c|c|c|c|c|}
\hline \multicolumn{5}{|c|}{ REPORT DOCUMENTATION PAGE } & $\begin{array}{l}\text { Form Approved } \\
\text { OMB No. 0704-0188 }\end{array}$ \\
\hline \multicolumn{6}{|c|}{ 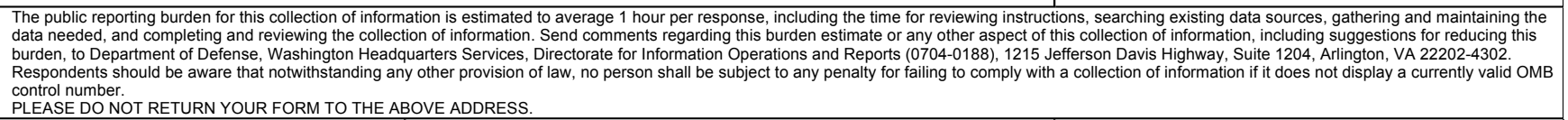 } \\
\hline \multicolumn{2}{|c|}{$\begin{array}{l}\text { 1. REPORT DATE (DD-MM-YYYY) } \\
01-01-2011\end{array}$} & \multicolumn{3}{|c|}{$\begin{array}{l}\text { 2. REPORT TYPE } \\
\text { Final Contractor Report }\end{array}$} & 3. DATES COVERED (From - To) \\
\hline \multirow{3}{*}{\multicolumn{5}{|c|}{$\begin{array}{l}\text { 4. TITLE AND SUBTITLE } \\
\text { Temperature and Atomic Oxygen Effects on Helium Leak Rates of a Candidate Main } \\
\text { Interface Seal }\end{array}$}} & $\begin{array}{l}\text { 5a. CONTRACT NUMBER } \\
\text { NNC08CA35C }\end{array}$ \\
\hline & & & & & 5b. GRANT NUMBER \\
\hline & & & & & 5c. PROGRAM ELEMENT NUMBER \\
\hline \multirow{3}{*}{\multicolumn{5}{|c|}{$\begin{array}{l}\text { 6. AUTHOR(S) } \\
\text { Penney, Nicholas; Wasowski, Janice, L.; Daniels, Christopher, C. }\end{array}$}} & 5d. PROJECT NUMBER \\
\hline & & & & & 5e. TASK NUMBER \\
\hline & & & & & $\begin{array}{l}\text { 5f. WORK UNIT NUMBER } \\
\text { WBS } 644423.06 .31 .04 .01 .03 .22\end{array}$ \\
\hline \multicolumn{5}{|c|}{$\begin{array}{l}\text { 7. PERFORMING ORGANIZATION NAME(S) AND ADDRESS(ES) } \\
\text { Ohio Aerospace Institute }\end{array}$} & $\begin{array}{l}\text { 8. PERFORMING ORGANIZATION } \\
\text { REPORT NUMBER } \\
\text { E-17458 }\end{array}$ \\
\hline \multirow{2}{*}{\multicolumn{5}{|c|}{$\begin{array}{l}\text { 9. SPONSORING/MONITORING AGENCY NAME(S) AND ADDRESS(ES) } \\
\text { National Aeronautics and Space Administration } \\
\text { Washington, DC 20546-0001 }\end{array}$}} & $\begin{array}{l}\text { 10. SPONSORING/MONITOR'S } \\
\text { ACRONYM(S) } \\
\text { NASA }\end{array}$ \\
\hline & & & & & $\begin{array}{l}\text { 11. SPONSORING/MONITORING } \\
\text { REPORT NUMBER } \\
\text { NASA/CR-2011-216830 }\end{array}$ \\
\hline \multicolumn{6}{|c|}{$\begin{array}{l}\text { 12. DISTRIBUTION/AVAILABILITY STATEMENT } \\
\text { Unclassified-Unlimited } \\
\text { Subject Categories: } 12,18 \text {, and } 37 \\
\text { Available electronically at http://gltrs.grc.nasa.gov } \\
\text { This publication is available from the NASA Center for AeroSpace Information, 443-757-5802 }\end{array}$} \\
\hline \multicolumn{6}{|c|}{ 13. SUPPLEMENTARY NOTES } \\
\hline \multicolumn{6}{|c|}{$\begin{array}{l}\text { 14. ABSTRACT } \\
\text { Helium leak tests were completed to characterize the leak rate of a } 54 \text { in. diameter composite space docking seal design in support of the } \\
\text { National Aeronautics and Space Administration's (NASA's) Low Impact Docking System (LIDS). The evaluated seal design was a } \\
\text { candidate for the main interface seal on the LIDS, which would be compressed between two vehicles, while docked, to prevent the escape of } \\
\text { breathable air from the vehicles and into the vacuum of space. Leak tests completed at nominal temperatures of }-30,20 \text {, and } 50{ }^{\circ} \mathrm{C} \text { on } \\
\text { untreated and atomic oxygen (AO) exposed test samples were examined to determine the influence of both test temperature and AO } \\
\text { exposure on the performance of the composite seal assembly. Results obtained for untreated seal samples showed leak rates which increased } \\
\text { with increased test temperature. This general trend was not observed in tests of the AO exposed specimens. Initial examination of collected } \\
\text { test data suggested that AO exposure resulted in higher helium leak rates, however, further analysis showed that the differences observed in } \\
\text { the } 20 \text { and } 50^{\circ} \mathrm{C} \text { tests between the untreated and AO exposed samples were within the experimental error of the test method. Lack of } \\
\text { discernable trends in the test data prevented concrete conclusions about the effects of test temperature and AO exposure on helium leak rates } \\
\text { of the candidate seal design from being drawn. To facilitate a comparison of the current test data with results from previous leak tests using } \\
\text { air as the test fluid, helium leak rates were converted to air leak rates using standard conversion factors for viscous and molecular flow. Flow } \\
\text { rates calculated using the viscous flow conversion factor were significantly higher than the experimental air leakage values, whereas values } \\
\text { calculated using the molecular flow conversion factor were significantly lower than the experimentally obtained air leak rates. The } \\
\text { difference in these sets of converted flow rates and their deviation from the experimentally obtained air leak rate data suggest that neither } \\
\text { conversion factor can be used alone to accurately convert helium leak rates to equivalent air leak rates for the test seals evaluated in this } \\
\text { study; other leak phenomena, including permeation, must also be considered. }\end{array}$} \\
\hline \multicolumn{6}{|c|}{$\begin{array}{l}\text { 15. SUBJECT TERMS } \\
\text { Spacecraft design; Testing; Performance; Mechanical engineering; Helium leak detection; Helium to air leak rate conversion }\end{array}$} \\
\hline \multicolumn{3}{|c|}{ 16. SECURITY CLASSIFICATION OF: } & $\begin{array}{l}\text { 17. LIMITATION OF } \\
\text { ABSTRACT }\end{array}$ & $\begin{array}{l}\text { 18. NUMBER } \\
\text { OF }\end{array}$ & $\begin{array}{l}\text { 19a. NAME OF RESPONSIBLE PERSON } \\
\text { STI Help Desk (email:help@sti.nasa.gov) }\end{array}$ \\
\hline $\begin{array}{l}\text { a. REPORT } \\
\text { U }\end{array}$ & $\begin{array}{l}\text { b. ABSTRACT } \\
\text { U }\end{array}$ & $\begin{array}{l}\text { c. THIS } \\
\text { PAGE } \\
\text { U }\end{array}$ & 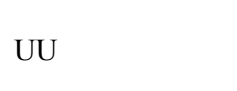 & $\begin{array}{l}\text { PAGES } \\
14\end{array}$ & $\begin{array}{l}\text { 19b. TELEPHONE NUMBER (include area code) } \\
443-757-5802\end{array}$ \\
\hline
\end{tabular}



